\title{
STRUKTUR POPULASI IKAN KURAU Polynemus dubius DI TELUK PALABUHANRATU
}

\section{POPULATION STRUCTURE OF EASTERN PARADISE FISH Polynemus dubius IN PALABUHANRATU BAY}

\author{
Julia Syahriani Hasibuan', Mennofatria Boer ${ }^{2}$, dan Yunizar Ernawati \\ ${ }^{1}$ Program Studi Pengelolaan Sumberdaya Perairan, Sekolah Pascasarjana, IPB \\ ${ }^{2}$ Departemen Manajemen Sumberdaya Perairan, FPIK-IPB \\ *E-mail: Syahrianijulia@gmail.com
}

\begin{abstract}
Palabuhanratu Bay has many fish resources, one of them is eastern paradise fish Polynemus dubius. Increasing fishing activity can affect population dynamics of eastern paradise fish. Changes in population dynamics can be seen by looking at the size and reproduction structure of fish. The purpose of this study was to analyze the status of the eastern paradise fish population in the Palabuhanratu bay through assessment of reproductive aspects and population dynamics during the months of MaySeptember 2017. The number of eastern paradise fish was 384 male and 556 female using stratified random sampling (PCAB). Data analysis consisted of length frequency distribution, length weight relationship, and sex ratio and gonad maturity stage. The results of the study showed that the ratio of male and female sex ratio was 1: 1.45 (unbalanced), the gonad maturity stage IV occurred in September was $68 \%$ of males and 38\% of females. The length weight relationship of eastern paradise fish has an isometric growth pattern dominated by gonad immature fish. Therefore, the population status of the eastern paradise fish in Palabuhanratu has shown overexploited with the reproductive aspect which shows that the TKG condition is not ideal, $L_{c}$ is smaller than $L_{m}$, and fishing in the spawning season will disrupt the eastern paradise fish sustainability while in terms of population dynamics, uniform fish growth shows lower fish growth potential and necessary precautionary approach for setting catch targets.
\end{abstract}

Keywords : length weight relationship, sex ratio, palabuhanratu bay, polynemus dubius

\begin{abstract}
ABSTRAK
Teluk Palabuhanratu memiliki banyak sumberdaya ikan, salah satunya adalah ikan kurau Polynemus dubius. Aktivitas penangkapan ikan yang terus-menerus dapat mempengaruhi dinamika populasi ikan kurau. Perubahan dinamika populasi dapat diketahui dengan melihat struktur ukuran dan reproduksi ikan. Tujuan penelitian ini adalah untuk menganalisis status populasi ikan kurau $P$. dubius di Teluk Palabuhanratu melalui pengkajian aspek reproduksi dan dinamika populasi selama bulan MeiSeptember 2017. Jumlah ikan kurau diperoleh sebanyak 384 ekor ikan jantan dan 556 ekor ikan betina dengan menggunakan metode Penarikan Contoh Acak Berlapis (PCAB). Analisis data terdiri atas sebaran frekuensi panjang, hubungan panjang bobot, serta rasio kelamin dan tingkat kematangan gonad. Hasil penelitiaan diperoleh bahwa rasio kelamin jantan dan betina adalah 1:1,45 (tidak seimbang), tingkat kematangan gonad IV terjadi pada bulan september sebesar $68 \%$ jantan dan $38 \%$ betina. Hubungan panjang bobot ikan kurau memiliki pola pertumbuhan isometrik didominasi oleh ikan belum matang gonad. Oleh karena itu, status populasi ikan kurau di Palabuhanratu sudah menunjukan overexploited dengan aspek reproduksi yang menunjukkan kondisi TKG yang tidak ideal, nilai $\mathrm{L}_{\mathrm{c}}<\mathrm{L}_{\mathrm{m}}$ dan menangkap pada musim pemijahan akan mengganggu keberlanjutan populasi ikan ini sedangkan dari sisi dinamika populasi, pertumbuhan ikan yang seragam menunjukkan potensi pertumbuhan ikan semakin rendah dan perlu kehati-hatian dalam menetapkan target tangkapan.
\end{abstract}

Kata kunci : hubungan panjang bobot, nisbah kelamin, Teluk Palabuhanratu, polynemus dubius 


\section{PENDAHULUAN}

Palabuhanratu merupakan salah satu daerah yang memiliki potensi sumberdaya perikanan laut yang cukup tinggi di Jawa Barat dan berhubungan langsung dengan Samudera Hindia yang dipandang sangat strategis karena berada pada posisi dekat dengan daerah penangkapan (fishing ground). Teluk Palabuharatu yang terletak di Kabupaten Sukabumi merupakan perairan yang berpotensi dalam hal penyediaan ikan pada masa yang akan datang (Wewengkang, 2002).

Ikan kurau Polynemus dubius merupakan salah satu ikan demersal yang ditangkap oleh nelayan di perairan palabuanratu. Ikan ini dipasarkan dalam bentuk segar maupun diasinkan. Ikan ini juga berperan dalam struktur trofik sebagai konsumen tingkat dua yaitu sebagai karnivora yang memakan ikan-ikan kecil, crustacea, moluska, polychaeta, dan echinodermata. Di Palabuhanratu, ikan ini ditangkap menggunakan jaring rampus dengan meshsize 3 inchi (Asyari dan Herlan, 2013).

Adanya kegiatan penangkapan yang dilakukan oleh nelayan menggunakan trammel net dengan ukuran mata jaring 1 inchi secara terus-menerus dapat mempengaruhi ketersediaan sumberdaya ikan kurau di Palabuanratu. Hal ini dapat dilihat dari berkurangnya stok ikan kurau selama penelitian dan semakin kecil ukuran sampel dari tahun-tahun sebelumnya yang nantinya akan berdampak pada peningkatan eksploitasi yang dapat memengaruhi kelestariannya (Nasution, 2009; Asyari and Herlan, 2013; Gebze and Latupeirissa, 2017).

Oleh karena itu, indikator biologi dan dinamika populasi dapat dipergunakan sebagai dasar pertimbangan pengelolaannya dalam menjaga kelestarian dengan mempertimbangkan prinsip kehati-hatian (Jamal et al., 2011). Penelitian tentang biologi reproduksi ikan dapat memberi data dan informasi penting mengenai frekuensi pemijahan, keberhasilan pemijahan, lama pemijahan, dan ukuran ikan ketika pertama kali mencapai kematangan gonad (Ashida and Masahiro, 2015). Penelitian ini bertujuan untuk menganalisis status populasi ikan kurau (P. dubius) di Teluk Palabuhanratu melalui pengkajian aspek reproduksi dan dinamika populasi.

\section{METODE PENELITIAN}

\subsection{Waktu dan Tempat Penelitian}

Penelitian ini dilakukan dengan menggumpulkan sampel ikan kurau yang ada di Pelabuhan Perikanan Nusantara (PPN) Palabuhanratu, Sukabumi, Jawa Barat (Gambar 1). Pengambilan ikan contoh dilakukan pada bulan Mei sampai September 2017 saat bulan gelap. Analisis ikan contoh dilakukan di Laboratorium Biologi Perikanan, Departemen Manajemen Sumberdaya Perairan, Fakultas Perikanan dan Ilmu Kelautan, Institut Pertanian Bogor.

\subsection{Pengumpulan Data}

Pengumpulan data primer ikan kurau dilakukan dengan menggunakan metode Penarikan Contoh Acak Berlapis (PCAB), yaitu dengan mengambil ikan secara acak dari keranjang nelayan yang sudah dikelompokkan. Pengambilan ikan contoh meliputi ikanikan yang berukuran kecil, sedang, dan besar setiap bulan pengamatan (Sarasati et al., 2016). Apabila ikan contoh tidak mencapai 200 ekor setiap jenisnya, maka dilakukan pengambilan ikan contoh yang mewakili secara acak berlapis dengan ukuran contoh yang diketahuinya (Boer, 1994). Ikan yang diamati hanya ikan yang ditangkap di perairan Palabuhanratu yang ditangkap menggunakan alat penangkap trammel net dengan mata jaring 1 inchi.

Jumlah sampel yang diperoleh sebanyak 940 ekor ikan kurau yang dikelompokkan berdasarkan kelas ukuran. Sampel ikan diukur panjang total, panjang baku, tinggi badan, lebar bukaan mulut, dan tinggi kepala menggunakan penggaris dengan ketelitian $1 \mathrm{~mm}$ serta bobot ikan ditimbang 

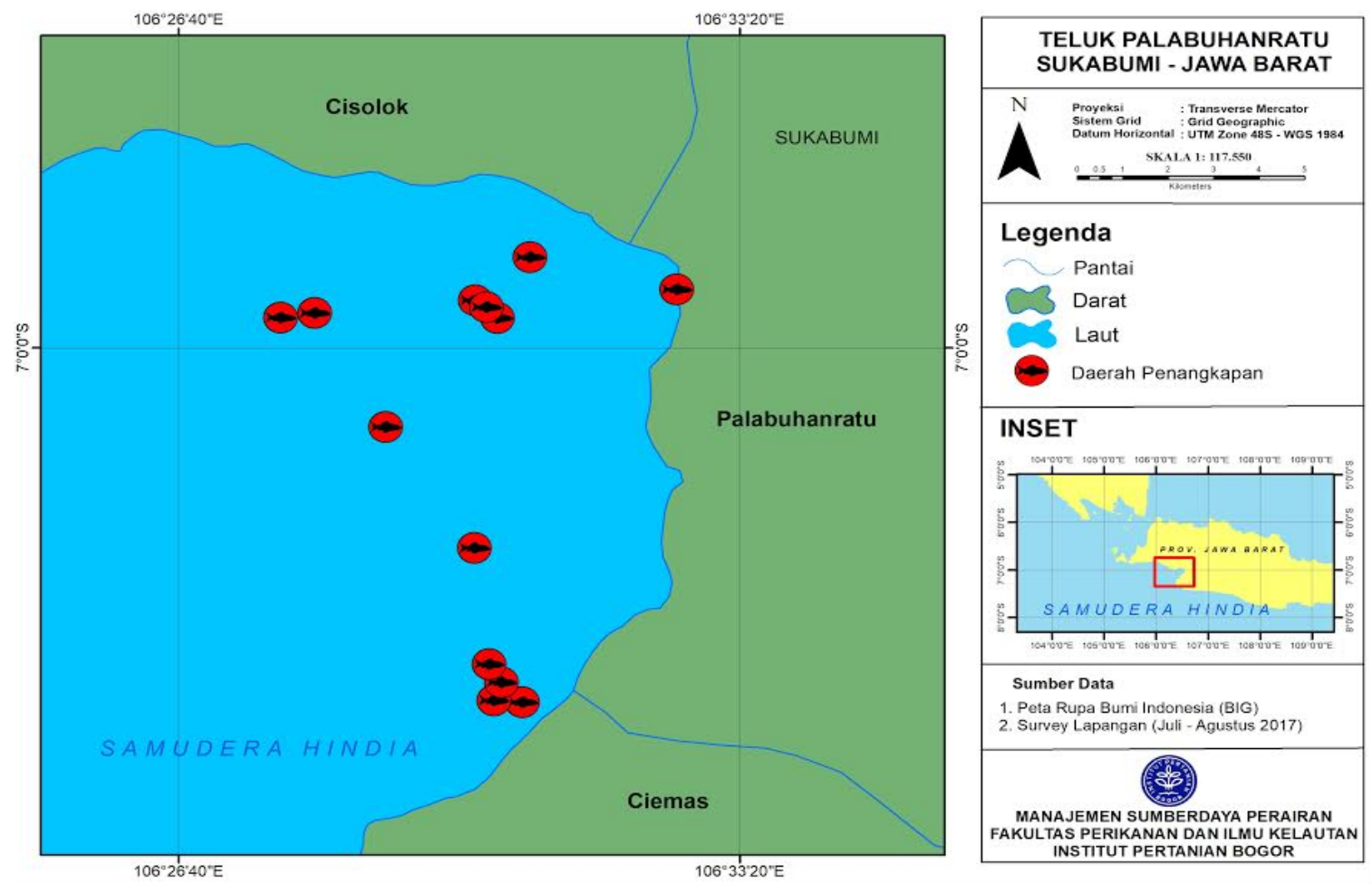

Gambar 1. Daerah penangkapan ikan kurau di Palabuhanratu.

menggunakan timbangan digital dengan ketelitian $0,01 \mathrm{~g}$. Setelah diukur, ikan dibedah untuk diamati gonadnya dalam penentuan jenis kelamin dan tingkat kematangan gonad. Kemudian gonad ditimbang menggunakan timbangan digital dengan ketelitian 0,0001 g.

\subsection{Analisis Data}

\subsubsection{Hubungan Panjang dan Bobot}

Analisis data panjang - bobot Model Allometric Linear (LAM) digunakan untuk menghitung parameter a dan $b$ melalui pengukuran perubahan bobot dan panjang sesuai dengan persamaan allometric berikut, berdasarkan De Robert and William (2008):

$W=a L^{b}$

Keterangan: W adalah bobot ikan (g), L adalah panjang total ikan ( $\mathrm{mm})$, a dan $\mathrm{b}$ adalah parameter.

Interpretasi dari hubungan panjang dan bobot dapat dilihat dari nilai konstanta $b$ yaitu dengan hipotesis:
1. $\mathrm{H} 0: \mathrm{b}=3$, dikatakan hubungan isometrik (pola pertumbuhan panjang sama dengan pola pertumbuhan bobot).

2. $\mathrm{H} 1: \mathrm{b} \neq 3$, dikatakan memiliki hubungan allometrik (panjang dan bobot tidak seimbang).

Pola pertumbuhan allometrik ada dua macam, yaitu allometrik positif $(b>3)$ yang mengindikasikan bahwa pertumbuhan bobot lebih dominan dibandingkan dengan pertumbuhan panjang dan allometrik negatif $(b<3)$ yang berarti bahwa pertumbuhan panjang lebih dominan dibandingkan dengan pertumbuhan bobotnya. Selanjutnya untuk menguji hipotesis tersebut, digunakan statistik uji sebagai berikut:

$$
\mathrm{t}_{\text {hitung }}=\left|\frac{b_{1}-b}{S b_{1}}\right|
$$

$\mathrm{Sb}_{1}$ adalah simpangan baku dugaan $\mathrm{b}_{1}$ atau $b$ yang dihitung dengan:

$\mathrm{Sb}_{1}=\frac{s^{2}}{\sum_{i=1}^{n} x_{1}{ }^{2}-\frac{1}{\mathrm{n}}\left(\sum_{i=1}^{n} x_{1}\right)^{2}}$ 
Selanjutnya, nilai $t_{\text {hitung }}$ dibandingkan dengan nilai $t_{\text {tabel }}$ pada selang kepercayaan 95\%. Pengambilan keputusannya adalah jika $t_{\text {hitung }}>\mathrm{t}_{\text {tabel }}$ maka tolak hipotesis nol $\left(\mathrm{H}_{0}\right)$ dan jika $t_{\text {hitung }}<\mathrm{t}_{\text {tabel }}$ berarti terima hipotesis nol (Walpole, 1995).

\subsubsection{Nisbah Kelamin}

Nisbah kelamin dapat dihitung dengan membandingkan antara jumlah ikan jantan dan ikan betina dengan persamaan sebagai berikut :

$$
\mathrm{N}_{\mathrm{k}}=\frac{M}{F}
$$

Keterangan: $\mathrm{N}_{\mathrm{k}}$ adalah nisbah kelamin, $\mathrm{M}$ adalah jumlah total ikan jantan (ekor), dan $\mathrm{F}$ adalah jumlah total ikan betina (ekor).

Hubungan antara jantan dan betina dalam suatu populasi diketahui dengan melakukan analisis nisbah kelamin ikan menggunakan uji Chi-square $\left(\mathrm{x}^{2}\right)$ (Steel and Torrie, 1993):

$\mathrm{X}^{2}=\frac{\Sigma\left(\mathrm{o}_{\mathrm{i}}-\mathrm{e}_{\mathrm{i}}\right)^{2}}{\mathrm{e}_{\mathrm{i}}}$

Keterangan: $\mathrm{x}^{2}$ adalah nilai bagi peubah acak yang sebaran penarikan contohnya menghampiri sebaran khi kuadrat (Chi-square), $\mathrm{o}_{i}$ adalah jumlah frekuensi ikan jantan dan betina yang teramati (ind), $e_{i}$ adalah jumlah frekuensi harapan dari ikan jantan dan betina (ind).

\subsubsection{Sebaran Frekuensi Panjang dan Identifikasi Kelompok Umur}

Sebaran frekuensi panjang ditentukan dari data panjang total ikan kurau. Data panjang ikan kurau dikelompokkan ke dalam beberapa kelas panjang sehingga setiap kelas panjang ke-i memiliki frekuensi $\left(f_{i}\right)$. Identifikasi kelompok umur dapat dilakukan dengan menganalisis frekuensi panjang dengan menggunakan metode ELEFAN I yang dikemas dalam paket program FISAT II (FAO-ICLARM Stock Assesment Tool). Sebaran frekuensi panjang dikelompokkan ke dalam beberapa kelompok umur yang menyebar normal dengan nilai rata-rata panjang dan simpangan baku pada masingmasing kelompok umur. Menurut Boer (1996) fungsi objektif yang digunakan untuk menduga $\{\hat{\mu}, \hat{\sigma}, \hat{\rho}\}$ adalah fungsi kemungkinan maksimum (maximum likelihood function):

$$
\mathrm{L}=\sum_{i=1}^{N} f_{i} \log \sum_{i=1}^{G} p_{j} q_{i j}
$$

Keterangan: $f_{i}$ adalah frekuensi ikan pada kelas panjang ke-i $(i=1,2, \ldots, \mathrm{N}), \mu_{\mathrm{j}}$ adalah rata-rata panjang kelompok umur ke- $j, \sigma_{j}$ adalah simpangan baku panjang kelompok umur ke-j, dan $\mathrm{p}_{j}$ adalah proporsi ikan dalam kelompok umur ke- $j(j=1,2, . ., \mathrm{G})$ sedangkan, yang merupakan fungsi kepekatan sebaran normal dengan nilai tengah $\mu_{\mathrm{j}}$ dan simpangan baku $\sigma_{\mathrm{j}}, \mathrm{x}_{\mathrm{i}}$ merupakan titik tengah kelas panjang ke- $i$, untuk menduga $\{\hat{\mu}, \hat{\sigma}, \hat{\rho}\}$ yang digunakan untuk menduga parameter pertumbuhan diperoleh dengan cara mencari turunan pertama $\mathrm{L}$ masing-masing terhadap $\mu_{\mathrm{j}}, \sigma_{\mathrm{j}}$, dan $\mathrm{p}_{\mathrm{j}}$.

$q_{i j}=\frac{1}{\sigma j \sqrt{2 \pi}} e^{\frac{1}{2}\left(\frac{x i-\mu j}{\sigma j}\right)^{2}}$

\subsubsection{Ukuran Pertama Kali Matang Gonad $\left(L_{m}\right)$ dan Ukuran Pertama Kali Tertangkap $\left(\mathbf{L}_{c}\right)$}

Rata-rata ukuran panjang pertama kali tertangkap $\left(\mathrm{L}_{\mathrm{c}}\right)$ dihitung dengan metode kantung berlapis (covered contents method). Hasil dari perhitungan tersebut membentuk kurva ogive selektifitas alat berbentuk sigmoid yang menyerupai kurva distribusi normal kumulatif yang diduga melalui metode Beverton dan Holt in Sparre dan Venema (1999):

$$
\mathrm{SL}=\frac{1}{1+\exp \left(a-b^{*} \mathrm{~L}\right)}
$$

Keterangan: SL adalah nilai estimasi ukuran panjang, L adalah nilai tengah panjang kelas $(\mathrm{mm})$, a dan $\mathrm{b}$ adalah konstanta, sedemikian 
sehingga, a dan $\mathrm{b}$ dapat dihitung melalui dugaan regresi linear:

$$
\ln \left(\frac{1}{\mathrm{SL}_{\mathrm{c}}}-1\right)=\mathrm{a}-\mathrm{b} * \mathrm{~L}
$$

Keterangan: $\mathrm{SL}_{\mathrm{c}}$ adalah frekuensi kumulatif relatif, L adalah nilai tengah panjang kelas (mm).

Adapun $\mathrm{L}_{\mathrm{c}}$ dapat dihitung melalui:

$$
\mathrm{L}_{\mathrm{c}}=-\frac{\mathrm{a}}{\mathrm{b}}
$$

Keterangan: $\mathrm{L}_{\mathrm{c}}$ adalah panjang ikan pertama kali tertangkap (mm), a dan b adalah konstanta.

Estimasi ukuran pertama kali matang gonad $\left(\mathrm{L}_{\mathrm{m}}\right)$ diduga dengan metode SpearmanKarber seperti yang diusulkan oleh Udupa (1986) sebagai berikut.

$$
\mathrm{m}=\left[\mathrm{xk}+\left(\frac{\mathrm{x}}{2}\right)\right]-\left(\mathrm{x} \sum \mathrm{p}_{\mathrm{i}}\right)
$$

dengan $\mathrm{L}_{\mathrm{m}}=$ antilog $\mathrm{m}$ dan selang kepercayaan $95 \%$ bagi log $\mathrm{m}$ dibatasi sebagai berikut:

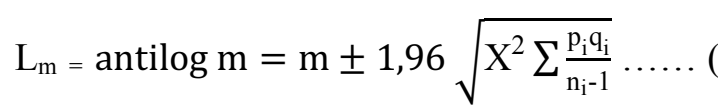

Keterangan: $m$ adalah log panjang ikan pada kematangan gonad pertama, $\mathbf{x}_{\mathrm{k}}$ adalah $\log$ nilai tengah kelas panjang yang terakhir dimana ikan telah matang gonad, $\mathrm{x}$ adalah log pertambahan panjang pada nilai tengah, $p_{i}$ adalah proporsi ikan matang gonad pada kelas panjang ke-i dengan jumlah ikan pada selang panjang, ke-i, $n_{i}$ adalah jumlah ikan pada kelas panjang ke-i, $\mathrm{q}_{\mathrm{i}}$ adalah $1-\mathrm{p}_{\mathrm{i}}$.

\subsubsection{Tingkat Kematangan Gonad}

Penentuan TKG dilakukan secara morfologi dengan memperhatikan bentuk, warna, ukuran gonad ikan contoh berdasarkan

\begin{tabular}{|c|c|c|}
\hline TKG & Betina & Jantan \\
\hline $\mathrm{I}$ & $\begin{array}{l}\text { Ovari seperti benang, } \\
\text { panjangnya sampai ke } \\
\text { depan rongga tubuh, } \\
\text { serta permukaannya licin }\end{array}$ & $\begin{array}{l}\text { Testis seperti benang,warna jernih, dan ujungnya } \\
\text { terlihat di rongga tubuh }\end{array}$ \\
\hline II & $\begin{array}{l}\text { Ukuran ovari lebih besar. } \\
\text { Warna ovari kekuning- } \\
\text { kuningan, dan telur } \\
\text { belum terlihat jelas }\end{array}$ & Ukuran testis lebih besar pewarnaan seperti susu \\
\hline III & $\begin{array}{l}\text { Ovari berwarna kuning } \\
\text { dan secara morfologi } \\
\text { telur mulai terlihat }\end{array}$ & $\begin{array}{l}\text { Permukaan testis tampak bergerigi, warna makin } \\
\text { putih dan ukuran makin besar }\end{array}$ \\
\hline IV & $\begin{array}{l}\text { Ovari makin besar, telur } \\
\text { berwarna kuning, mudah } \\
\text { dipisahkan. Butir minyak } \\
\text { tidak tampak, mengisi } \\
\text { 1/2-2/3 rongga perut }\end{array}$ & $\begin{array}{l}\text { Dalam keadaan diawet mudah putus, testis } \\
\text { semakin pejal }\end{array}$ \\
\hline V & $\begin{array}{l}\text { Ovari berkerut, dinding } \\
\text { tebal, butir telur sisa } \\
\text { terdapat didekat } \\
\text { pelepasan }\end{array}$ & $\begin{array}{l}\text { Testis bagian belakang kempis dan dibagian dekat } \\
\text { pelepasan masih berisi }\end{array}$ \\
\hline
\end{tabular}
metode Cassie (1956) dapat dilihat pada Tabel 1.

Tabel 1. Penentuan TKG dilakukan secara morfologi berdasarkan metode Cassie (1956). 


\section{HASIL DAN PEMBAHASAN}

\subsection{Hasil}

\subsubsection{Hubungan Panjang-Bobot}

Pendugaan pola pertumbuhan ikan kurau jantan dan betina berdasarkan hasil uji$\mathrm{t}$, memiliki nilai $t_{\text {hitung }}<\mathrm{t}_{\text {tabel }}$ yaitu dengan nilai masing-masing sebesar 2,0896<2,2503 dan $1,4385<2,2475$ yang berarti memiliki pola pertumbuhan isometrik $(b=3)$ dengan persamaan $\mathrm{W}=0,000016343 \mathrm{~L}^{2,8380}$ pada jantan dan $\mathrm{W}=0,000004923 \mathrm{~L}^{3,0855}$ pada betina.

Nilai koefisien determinasi ikan kurau menunjukkan bahwa ikan kurau jantan maupun betina memiliki hubungan yang sangat erat dengan nilai $\mathrm{R}^{2}$ masing-masing $78,01 \%$ dan 82,95\% disajikan pada Gambar 2.

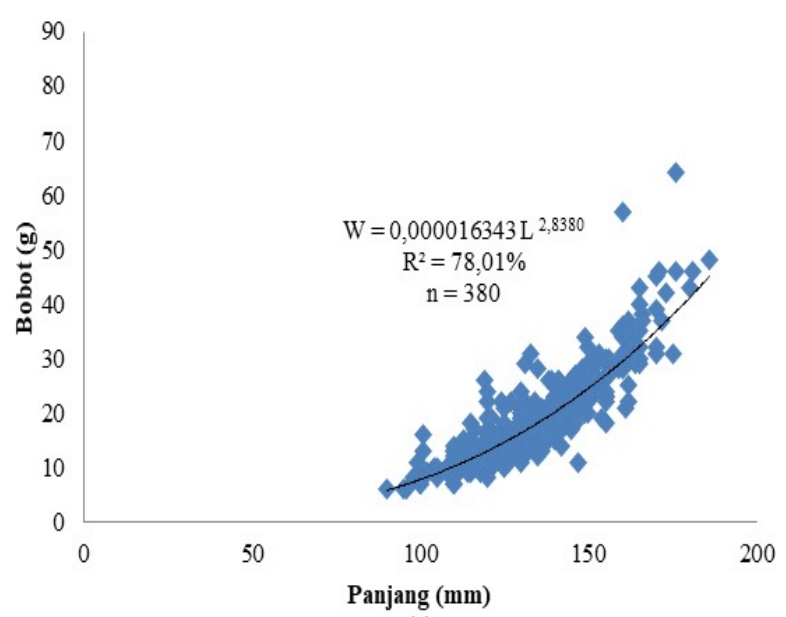

(a)

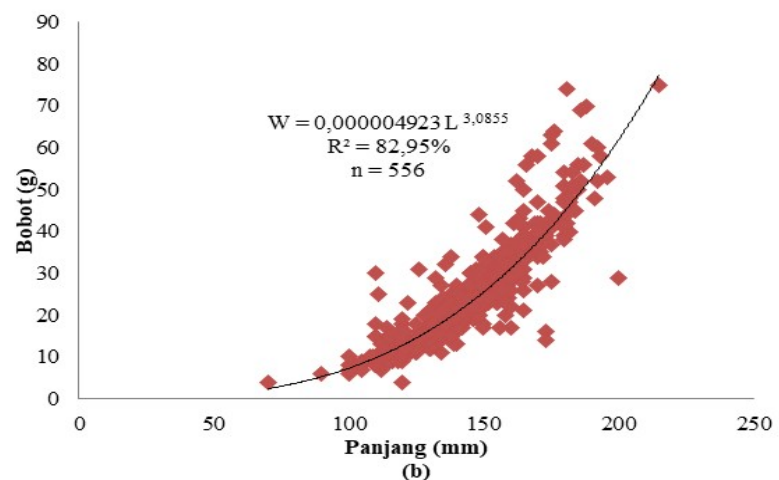

Gambar 2. Hubungan panjang bobot ikan kurau selama penelitian (a) jantan, (b) betina.

\subsubsection{Nisbah Kelamin}

Jenis kelamin jantan dan betina dapat ditentukan secara morfologi melalui pengamatan bentuk dan warna gonad ikan kurau (P. dubius). Nisbah kelamin ikan kurau menunjukan bahwa pada bulan Juni, Juli, dan September tidak 1:1 sementara pada bulan Mei dan Agustus memiliki rasio kelamin 1:1. Jumlah keseluruhan contoh ikan kurau yang diamati adalah 940 ekor, yang terdiri dari ikan kurau jantan dan betina masing-masing sebanyak 384 ekor dan 556 ekor. Rasio total perbandingan ikan jantan dan betina yang diperoleh adalah 1:1,45. Hasil Uji Chi-square dengan selang kepercayaan 95\% menunjukkan bahwa perbandingan ikan kurau jantan dan betina tidak 1:1. Rasio kelamin ikan kurau berdasarkan waktu pengambilan contoh disajikan pada Tabel 2.

Tabel 2 Rasio kelamin ikan kurau (P. dubius) selama penelitian.

\begin{tabular}{lccccccc}
\hline \multirow{2}{*}{$\begin{array}{l}\text { Pengambilan } \\
\text { contoh }\end{array}$} & Jumlah & \multicolumn{2}{c}{ Sampel (n) } & Rasio & Uji Chi-Square & \multirow{2}{*}{ Ket. } \\
& sampel (N) & Jantan & Betina & Kelamin & X & \\
\hline Mei & 216 & 100 & 116 & $1: 1,16$ & 1,18 & Terima H0 \\
Juni & 84 & 9 & 75 & $1: 8,33$ & 51,85 & Tolak H0 \\
Juli & 201 & 81 & 120 & $1: 1,48$ & 7,56 & Tolak H0 \\
Agustus & 139 & 72 & 67 & $1: 0,93$ & & 0,18 & Terima H0 \\
September & 300 & 122 & 178 & $1: 1,46$ & 10,45 & Tolak H0 \\
Total & 940 & 384 & 556 & $1: 1,45$ & & 31,47 & Tolak H0 \\
\hline
\end{tabular}

Keterangan: $\mathrm{H} 0=$ perbandingan antara jumlah ikan jantan dan betina $1: 1 ; \mathrm{H} 1=$ perbandingan antara jumlah ikan jantan dan betina tidak $1: 1$. 


\subsubsection{Sebaran Frekuensi Panjang dan Identifikasi Kelompok Umur}

Berdasarkan sampel yang diamati sebanyak 940 ekor ikan kurau, sebaran frekuensi panjang ikan kurau menyebar dari selang kelas panjang $90 \mathrm{~mm}-219 \mathrm{~mm}$ (Gambar 3). Frekuensi tertinggi jantan terdapat pada selang kelas $130-134 \mathrm{~mm}$ dan betina pada $150-154 \mathrm{~mm}$.

Pendugaan kelompok umur ikan dapat diketahui dari analisis sebaran frekuensi panjang total dari ikan kurau. Menurut
Kamarullah (2016), salah satu informasi penting dalam pengkajian suatu populasi ikan adalah struktur ukuran. Panjang total kedua ikan ini dijadikan ukuran dalam pengkajian stok ini. Data pengukuran panjang ikan kurau betina dan jantan selama penelitian disajikan pada Gambar 4 menyajikan kurva pertumbuhan ikan dari hasil analisis dengan menggunakan ELEFAN. Pergeseran modus ikan kurau betina dan jantan ke arah kanan menunjukkan adanya pertumbuhan ikan ini.

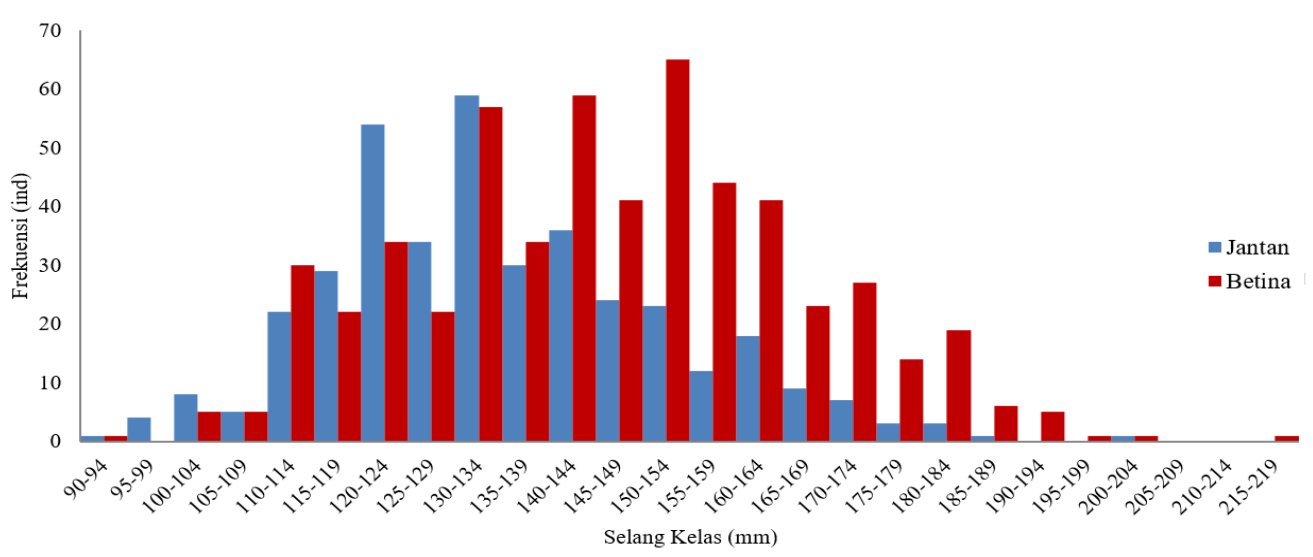

Gambar 3. Sebaran frekuensi panjang ikan kurau (P. dubius) selama penelitian.

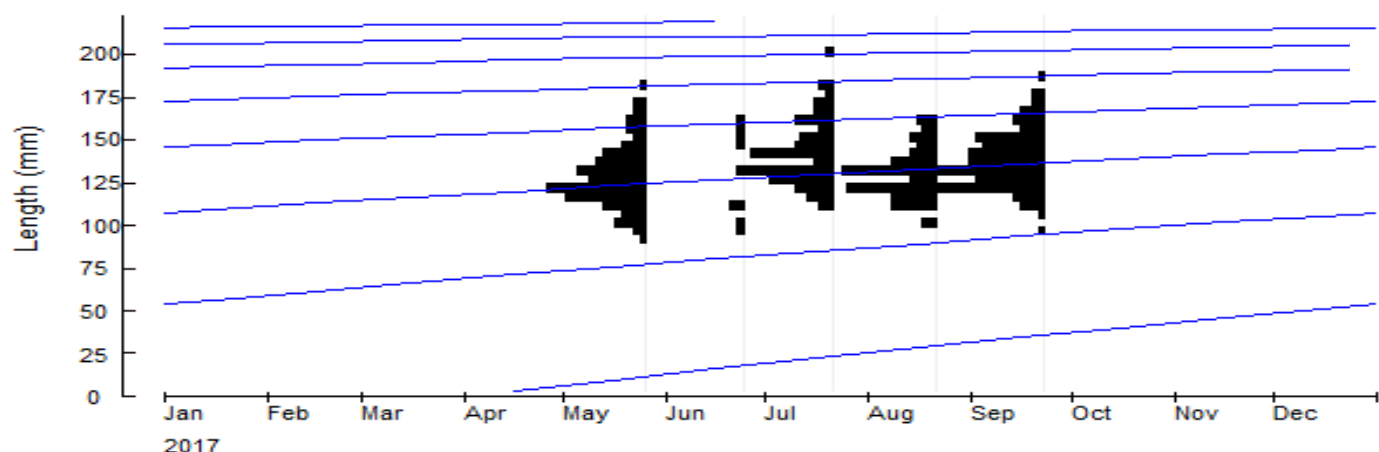

(a)

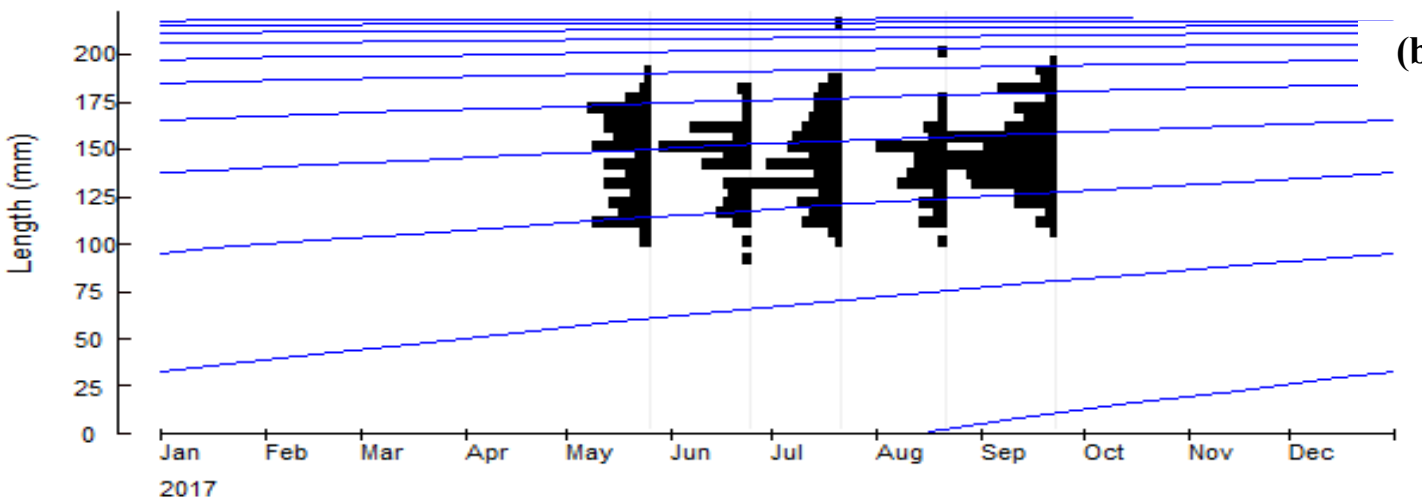

(b)

Gambar 4. Grafik pergeseran modus frekuensi panjang ikan kurau (P. dubius) (a) jantan dan (b) betina selama setahun. 


\subsubsection{Ukuran Pertama Kali Tertangkap dan Ukuran Pertama Kali Matang Gonad}

Menurut Permatachani et al. (2016), panjang pertama kali tertangkap $\left(\mathrm{L}_{\mathrm{c}}\right)$ ialah panjang ikan yang ke-50\% dari ikan tertangkap di suatu perairan. Panjang ikan pertama kali matang gonad $\left(\mathrm{L}_{\mathrm{m}}\right)$ dianalisis berdasarkan tingkat kematangan gonad (TKG), sedangkan untuk ukuran pertama kali ikan tertangkap dihitung menggunakan data frekuensi dan selang kelas panjang ikan. Pendugaan ukuran panjang pertama kali matang gonad dengan menggunakan Tingkat Kematangan Gonad III dan IV. Ukuran pertama kali matang gonad $\left(\mathrm{L}_{\mathrm{m}}\right)$ ikan kurau jantan dan betina masing-masing adalah $168,1454 \mathrm{~mm}$ dan $144,7069 \mathrm{~mm}$. Ukuran panjang pertama kali ikan kurau tertangkap $\left(L_{c}\right)$ diperoleh nilai jantan sebesar 134,6919 $\mathrm{mm}$ dan betina sebesar $144,7927 \mathrm{~mm}$. Ukuran panjang pertama kali matang gonad dan ukuran panjang pertama kali ikan kurau tertangkap disajikan pada Gambar 5.
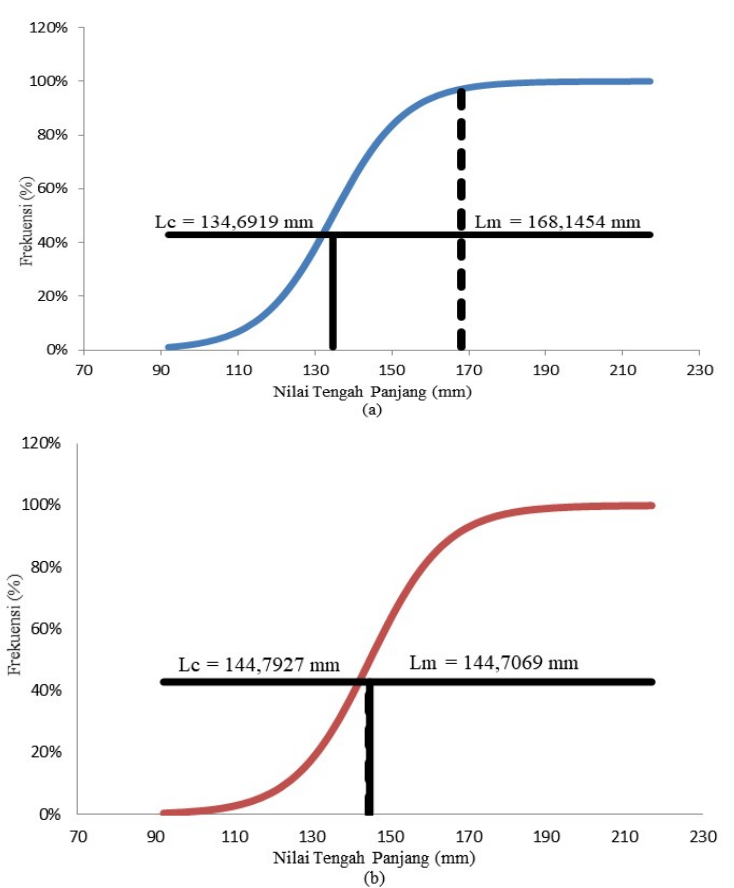

Gambar 5. Ukuran pertama kali matang gonad ikan kurau ( $P$. dubius) (a) jantan dan (b) betina selama penelitian.

\subsubsection{Tingkat Kematangan Gonad}

Berdasarkan pengamatan secara morfologi ikan kurau diperoleh TKG I hingga TKG V. Frekuensi ikan kurau betina dengan TKG matang gonad ditemukan pada setiap bulan pengamatan, sehingga pemijahan terindikasi berlangsung dari bulan MeiSeptember. Frekuensi relatif ikan kurau TKG IV tertinggi ditemukan pada bulan September sebesar $68,00 \%$ jantan dan 38,00\% betina (Gambar 6).

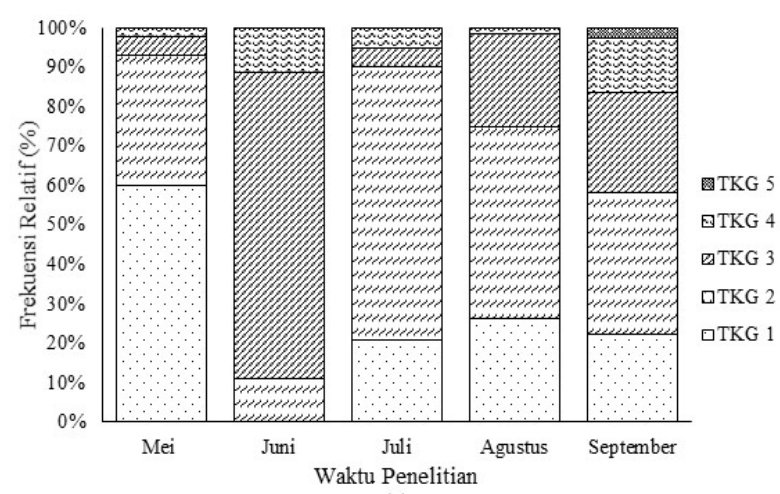

(a)

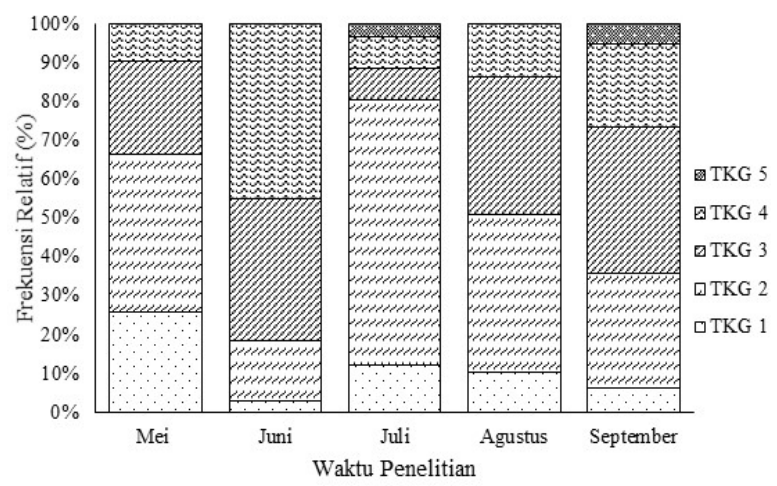

(b)

Gambar 6. Tingkat kematangan gonad ikan kurau (P. dubius) berdasarkan waktu penelitian; (a) jantan dan (b) betina.

Tingkat kematangan gonad ikan pada setiap selang kelas panjang dapat dilihat pada Gambar 7. Pada ikan kurau jantan, TKG I terdapat pada selang kelas 90-180 mm, TKG II pada selang kelas 90-206 mm, TKG III pada selang kelas 90-180 mm dan TKG IV pada selang kelas 90-206 mm. Sementara ikan kurau betina, TKG I terdapat pada selang kelas 90-180 mm, TKG II pada selang kelas 90-206 mm, TKG III pada selang kelas 90- 
193 mm, TKG IV pada selang kelas 103-219 mm, dan TKG V pada selang kelas 116-180 $\mathrm{mm}$.

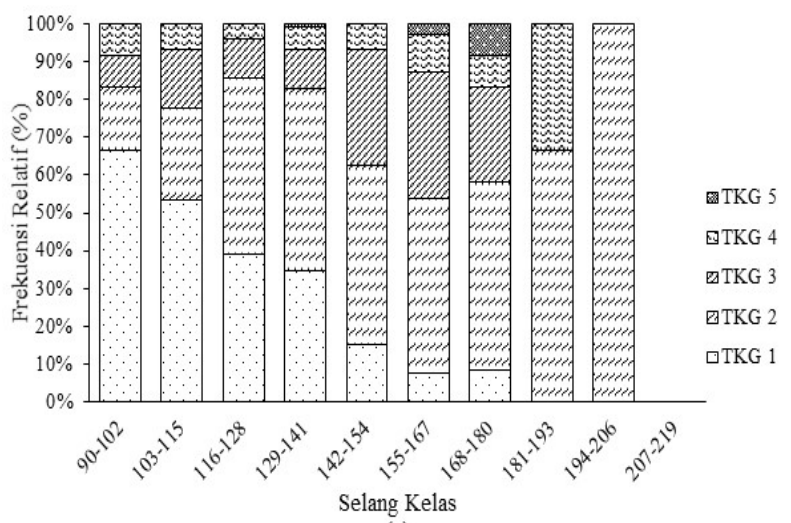

(a)

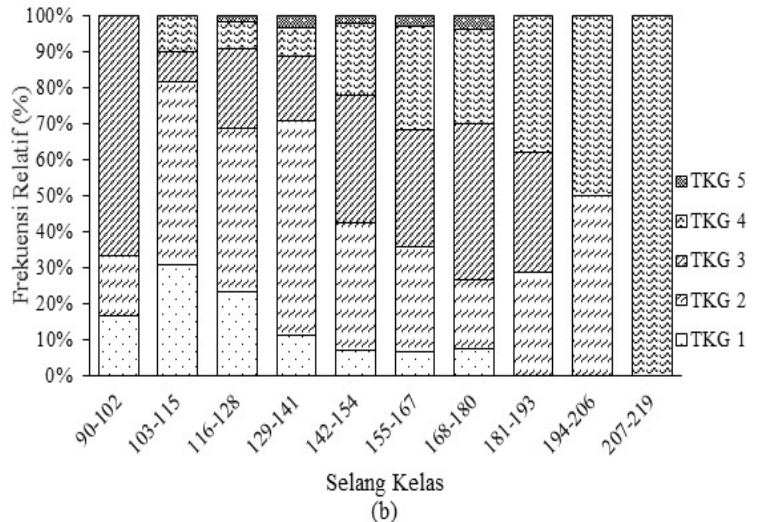

Gambar 7. Tingkat kematangan gonad ikan kurau (P. dubius) berdasarkan selang kelas; (a) jantan dan (b) betina.

\subsection{Pembahasan}

Pendugaan pola pertumbuhan ikan kurau jantan dan betina di Palabuhanratu berdasarkan hasil uji-t, ternyata nilai $b$ ikan kurau jantan dan betina ini tidak berbeda nyata dengan nilai 3 ( $\mathrm{t}_{\text {hitung }}<\mathrm{t}_{\text {tabel }}$ ) masingmasing 2,8380 dan 3,0855. Dengan demikian ikan kurau mempunyai pola pertumbuhan yang isometrik dimana terdapat keseimbangan antara pertumbuhan panjang dengan pertumbuhan bobot. Hal ini sesuai dengan penelitian Suruwaky dan Gunaisah (2013) yang menjelaskan bahwa jika nilai b tidak sama dengan tiga maka pertumbuhannya allometrik. Jika nilai $b<3$ menunjukkan keadaan ikan yang kurus dimana pertambahan panjangnya lebih cepat dari pertambahan bobotnya dan jika nilai $b>3$ maka menunjukkan ikan gemuk dimana pertambahan bobot lebih cepat dari pertambahan panjangnya.

Hasil penelitian ini sesuai dengan yang dilakukan oleh penelitian Djamali et al. (1988) terhadap ikan kurau dari famili Polynemidae lainnya yaitu ikan senangin (Eleutheronema tetradactylum) di muara Sungai Musi menunjukkan bahwa nilai $b$ untuk ikan kurau sebesar 3,038 dan setelah melalui uji-t menunjukkan bahwa pola pertumbuhannya adalah isometrik. Sementara hasil berbeda yang dilakukan pada penelitian Muthmainnah (2008) mendapatkan pola pertumbuhan yang bersifat alometrik negatif untuk ikan janggutan (Polynemus longipectoralis) di estuari Sungai Musi, yang berarti pertumbuhan panjang lebih cepat dari pertumbuhan bobot. Menurut penelitian Gebze dan Latupeirissa (2017) menyatakan bahwa ikan kurau jantan yang ditemukan di perairan Muara Sungai Kumbe adalah allometrik positif.

Adanya perbedaan pada pertambahan antara bobot dan panjang dapat disebabkan ikan yang tertangkap didominasi oleh ikan ukuran kecil, yang pertumbuhan panjangnya lebih cepat daripada bobotnya (Nasution, 2005). Pengaruh ukuran panjang dan bobot tubuh ikan sangat besar terhadap nilai $b$ yang diperoleh sehingga secara tidak langsung faktor-faktor yang berpengaruh terhadap ukuran tubuh ikan akan mempengaruhi pola variasi dari nilai b (Ibrahim et al., 2017). Ketersediaan makanan, tingkat kematangan gonad, dan variasi ukuran tubuh ikan contoh juga dapat menjadi penyebab perbedaan nilai b (Suwarni, 2009). Selain itu juga dapat dipengaruhi oleh tingkah laku ikan yang melakukan pergerakan aktif dan ruaya (Utami et al., 2014). Pengukuran panjang bobot yang dihubungkan dengan umur dapat memberikan informasi tentang komposisi stok, umur matang gonad, mortalitas, siklus hidup dan pertumbuhan (Fatioye and Oluajo, 2005). 
Rasio kelamin dapat digunakan untuk melihat populasi ikan dalam mempertahankan kelestariannya.

Rasio kelamin yang seimbang (1:1) sering digunakan sebagai indikator biologi, berkaitan dengan keseimbangan jumlah populasi ikan jantan dengan betina untuk menunjang keberhasilan reproduksi (Effendie, 2002). Adapun seringkali terjadi perbedaan dari pola 1:1. Hal ini berkaitan dengan pemijahan ikan yang diduga secara eksternal dengan fekunditas ikan betina yang tinggi, sehingga memerlukan populasi ikan jantan yang lebih dari betina. Perubahan rasio kelamin saat frekuensi relatif TKG IV tertinggi disebabkan tingkah laku ikan saat memijah. Rasio kelamin tersebut mengindikasikan satu ekor ikan betina akan dibuahi oleh dua ekor ikan jantan (Patnaik, 1970).

Rasio kelamin ikan kurau menunjukan bahwa perbandingan ikan jantan dan betina yang diperoleh adalah 1:1,45. Hasil Uji Chisquare dengan selang kepercayaan 95\% menunjukkan bahwa perbandingan ikan kurau jantan dan betina tidak 1:1. Apabila nisbah kelamin ikan di alam tidak seimbang adalah sebagai pertanda bahwa kondisi lingkungan perairan tersebut telah terganggu. Menurut Nikolsky (1980) nisbah kelamin optimum bisa berubah secara drastis karena dipengaruhi oleh banyak faktor. Perubahan nisbah kelamin dari 1:1 adalah karena adanya perubahan suhu perairan, ikan betina mudah dimangsa predator, resiko alami dan fase migrasi populasi induk ikan betina berbeda dengan induk ikan jantan.

Sebaran frekuensi panjang ikan kurau menyebar dari selang kelas panjang $90 \mathrm{~mm}$ $219 \mathrm{~mm}$. Frekuensi tertinggi terdapat pada selang kelas 130-134 mm pada jantan sementara $150-154 \mathrm{~mm}$ pada betina. Hal ini berbeda pada penelitian Djamali et al., (1988) dengan ikan kurau (Eleutheronema tetradactylum) yang tertangkap di daerah muara Sungai Musi, Sumatera Selatan yang berukuran 113-380 $\mathrm{mm}$ dan di daerah perairan Utara Australia yang berukuran 203-815 mm (Ballagh et al., 2011). Menurut Ashida and
Masahiro (2015), menjelaskan bahwa jika pada suatu perairan terdapat perbedaan ukuran dan jumlah ikan, hal tersebut mungkin disebabkan oleh perbedaan pola pertumbuhan, perbedaan ukuran pertama kali matang gonad, perbedaan masa hidup, dan adanya pemasukan jenis ikan atau spesies baru pada suatu populasi ikan yang sudah ada. Spesies ikan yang sama dan hidup di lokasi perairan yang berbeda akan mengalami pertumbuhan yang berbeda karena adanya faktor dalam dan faktor luar yang memengaruhi pertumbuhan ikan tersebut. Faktor dalam tersebut, yaitu faktor yang umumnya sulit dikontrol, seperti keturunan, jenis kelamin, umur, serta penyakit (Effendie, 2002). Faktor luar yang utama memengaruhi petumbuhan ikan adalah suhu dan makanan (Manik, 2007).

Metode yang digunakan untuk analisis pergeseran modus frekuensi panjang ikan kurau ( $P$. dubius) adalah metode ELEFAN I melalui program FISAT II dapat juga digunakan untuk pendugaan pertumbuhan panjang ikan. Pergeseran modus ikan kurau selama waktu pengamatan bergerak kearah kanan yang menunjukan adanya pertumbuhan pada ikan kurau. Data yang diperoleh dari program FISAT adalah frekuensi kelas ukuran yang dilakukan selama 5 kali pengukuran. Hasil perhitungan diperoleh nilai $\mathrm{L}_{\infty}$ adalah $240 \mathrm{~mm}$; k adalah 0,34 pada ikan jantan dan 223,25 mm ; 0,4 pada ikan betina sehingga panjang maksimum ikan kurau yang didaratkan di Palabuhanratu adalah $240 \mathrm{~mm}$.

Pendugaan ukuran pertama kali matang gonad merupakan salah satu cara untuk mengetahui perkembangan populasi dalam suatu perairan, seperti ikan akan memijah, baru memijah atau sudah selesai memijah (Najamuddin et al., 2004). Ukuran pertama kali matang gonad $\left(\mathrm{L}_{\mathrm{m}}\right)$ ikan kurau jantan dan betina masing-masing adalah $168,1454 \mathrm{~mm}$ dan $144,7069 \mathrm{~mm}$. Menurut Sulistiono et al., (2009), ukuran setiap ikan untuk mencapai ukuran pertama kali matang gonad berbeda, dan memiliki hubungan dengan pertumbuhan serta strategi re- 
produksinya. Ukuran panjang pertama kali ikan kurau tertangkap $\left(\mathrm{L}_{\mathrm{c}}\right)$ diperoleh nilai jantan sebesar 134,6919 $\mathrm{mm}$ dan betina sebesar 144,7927 mm. Ukuran panjang ikan kurau pertama kali tertangkap lebih kecil dibandingkan dengan ukuran panjang pertama kali matang gonad, dimana nilai $\mathrm{L}_{\mathrm{c}}<\mathrm{L}_{\mathrm{m}}$ menunjukkan ikan yang belum matang gonad sudah tertangkap. Oleh karena itu untuk menjaga kelestarian sumberdaya perikanan, sebaiknya ikan-ikan ditangkap yang lebih besar dari ukuran $\mathrm{L}_{\mathrm{m}}\left(\mathrm{L}_{\mathrm{c}}>\mathrm{L}_{\mathrm{m}}\right)$.

Menurut Permatachani et al., (2016), nilai $\mathrm{L}_{\mathrm{m}}$ antara jantan dan betina berbeda karena ukuran pada waktu matang gonad ikan pada ukuran yang sama belum tentu mempunyai ukuran pertama kali matang gonad pada umur atau panjang yang sama. Selain itu adanya faktor-faktor seperti suhu, makanan, hormon, jenis kelamin, dan kondisi perairan. Keberlanjutan perikanan tangkap sebaiknya didukung oleh peraturan yang menetapkan ukuran ikan yang layak tangkap, yaitu ikan yang memiliki panjang yang lebih besar dari panjang pertama kali ikan matang gonad. Banyaknya ukuran ikan yang tidak layak ditangkap menggambarkan bahwa nelayan belum mengetahui bulan-bulan penangkapan yang tidak berpengaruh terhadap keberlanjutan sumberdaya perikanan dan usaha perikanan. Ikan yang tertangkap sebelum matang gonad, diduga ikan tersebut belum sempat memijah, sehingga hal ini akan berpengaruh terhadap rekruitmen di perairan tersebut (Suwarni, 2009).

Tingkat kematangan gonad I dan II ikan kurau di Palabuhanratu sebesar 72,34\%. Kondisi ini menunjukkan bahwa telah terjadi gejala recruitment overfishing stok ikan kurau di perairan Palabuanratu. Sementara sebanyak $27,66 \%$ sudah mencapai fase kematangan dan reproduksi. Berdasarkan hasil pengamatan dapat diduga bahwa ikan betina lebih cepat matang gonad pada ukuran yang lebih pendek daripada ikan jantan. Umumnya ikan yang berukuran kecil lebih cepat matang gonad daripada ikan berukuran besar. Menurut Effendie (2002), ikan yang sudah mencapai
TKG III dan IV dapat merupakan indikator adanya ikan yang memijah pada perairan tersebut. Pemijahan ikan dilakukan pada saat kondisi lingkungan mendukung keberhasilan pemijahan dan kelangsungan hidup larva. Dari hasil pengamatan tingkat kematangan gonad, diperkirakan ikan kurau mengalami pemijahan secara bertahap (parsial) sesuai dengan persentase tingkat kematangan dari bulan ke bulan. Tingkat kematangan gonad ikan dapat memberikan keterangan yang berarti mengenai frekuensi, musim pemijahan, ukuran ikan pertama kali matang gonad dan memijah (Nikolsky, 1980). Aktivitas penangkapan bulan Mei hingga September cenderung menangkap ikan yang masih tumbuh menuju populasi matang gonad. Bila kondisi ini sama dengan bulan lainnya, sangat berpotensi mengganggu kelangsungan populasi menjadi ikan dewasa sehingga proses regenerasi bisa terhambat.

\section{KESIMPULAN}

Status populasi ikan kurau di Palabuhanratu sudah menunjukan over exploitation. Dinamika populasi, pertumbuhan ikan ini seragam sehingga potensi pertumbuhan ikan semakin rendah dan perlu kehati-hatian dalam menetapkan target tangkapan, Dari sisi reproduksi, kondisi TKG yang tidak ideal dimana ikan yang muda dominan tertangkap, nilai $\mathrm{L}_{\mathrm{c}}<\mathrm{L}_{\mathrm{m}}$ dimana penangkapan ikan yang berukuran kecil ditangkap sebelum mencapai matang gonad, dan menangkap pada musim pemijahan akan mengganggu keberlanjutan populasi ikan ini.

\section{UCAPAN TERIMA KASIH}

Penelitian ini dibiayai dengan dana penelitian dari Direktorat Riset dan Pengabdian Masyarakat Direktorat Jenderal Penguatan Riset dan Pengembangan Kementerian Riset, Teknologi dan Pendidikan Tinggi dengan Surat Perjanjian Penugasan Pelaksanaan Program Penelitian Nomor: 011/SP2H/LT/DRPM/IV/2017, 20 April 2017 
dan Addendum Kontrak No.: 011/SP2 H/LT/DRPM/VIII/2017 21 Agustus 2017.

\section{DAFTAR PUSTAKA}

Asyari dan Herlan. 2013. Beberapa aspek biologi ikan kurau (Polynemus dubius) di estuari sungai Indragiri, Riau. $J$. Bawal, 5(2):67-72. http://dx.doi. org/10.15578/bawal.5.2.2013.67-72

Ashida, H. and H. Masahiro 2015. Reproductive condition, spawning season, batch fucundity and spawning fraction of skipjack tuna (Katsuwonus pelamis) caught around Amami Oshima, Kagoshima, Japan. J. Fish Sci, 81:861-869. https://doi.org/ 10.1007/s12562-015-0909-0

Ballagh, A.C., D.J. Welch, S.J. Newman, Q. Allsop, and J.M. Stapley. 2011. Stock structure of the blue threadfin (Eleutheronema tetradactylum) across northen Australia derived from lifehistory characteristics. J. Fisheries Research, 64:121-122. https://doi.org/ 10.1016/j.fishres.2012.01.011

Boer, M. 1996. Pendugaaan koefisien pertumbuhan $\left(\mathrm{L}_{\infty}, \mathrm{K}, \mathrm{t}_{0}\right)$ berdasarkan data frekuensi panjang. J. Ilmu-ilmu Perairan dan Perikanan Indonesia, 4(1): 75-84.

De Robert, A. and K. William. 2008. Weightlength relationship in fisheries studies: the standard allometric model should be applied with caution. J. Transaction of the American Fisheries Society, 137:707-719. https://doi.org/10.1577/ T07-124.1.

Djamali, A., Burhanuddin, dan S. Martosewojo. 1988. Telaah biologi ikan kurau (Eleutheronema tetradactylum) Polynemidae di muara Sungai Musi Sumatera Selatan. J. Pusat Penelitian dan Pengembangan Osenologi, 1(1): 83-86.

Effendie, M.I. 2002. Biologi perikanan. Yayasan Pustaka Nusantara. Yogyakarta. $64 \mathrm{hlm}$.
Fatioye, O.O. and O. A. Oluajo. 2005. Length weight relationships of five fish species in Epe Lagoon, Negeria. $J$. African of biotechnology, 4(7): 749751. http://dx.doi.org/10.5897/AJB 2005.000-3136.

Gebze, A.K. and I.L. Latupeirissa. 2017. Pertumbuhan ikan kuro (Eleutheronema tetradactylum Shaw, 1804) di Muara Sungai Kumbe Kabupaten Merauke. J. Agricola. 7 (1):129-135.

Ibrahim, P.S., S. Isdradjad, dan Sulistiono. 2017. Hubungan panjang bobot dan faktor kondisi ikan selar kuning (Selaroides leptolepis) di Perairan Selat Sunda. J. Ilmu dan Teknologi Kelautan Tropis, 9(2):577-584. http://dx.doi.org/10.29244/jitkt.v9i2.1 9292.

Jamal, M., M.F.A. Sondita, J. Haluan, dan B. Wiryawan. 2011. Pemanfaatan data biologi ikan cakalang (Katsuwonus pelamis) dalam rangka pengelolaan perikanan bertanggung jawab di Perairan Teluk Bone. J. Natur Indonesia, 14(1):107-113.

Kamarullah, M.C. 2016. Dinamika populasi dan biologi reproduksi ikan swanggi (Priacanthus tayenus Richardson, 1846) (Studi Kasus Perairan Selat Sunda) Provinsi Banten. Tesis. Institut Pertanian Bogor. Bogor. 77 hlm.

Manik, N. 2007. Beberapa aspek biologi ikan cakalang (Katsuwonus pelamis) di Perairan Sekitar Pulau Seram Selatan dan Pulau Nusa Laut. J. Oseanologi dan Limnologi di Indonesia, 33:17-25.

Muthmainnah, D. 2008. Length-weight relationship and food habits of Polynemus longipectoralis in lower part of Musi River. J. Marine and Fish. Research Agency, 4(1): 51-54.

Najamuddin, A. Mallawa, Budimawan, dan Y.N. Indar. 2004. Pendugaan ukuran pertama kali matang gonad ikan layang deles (Decapterus macrosoma 
Bleeker). J. Sains dan Teknologi, 4(1): 1-8.

Nasution, S.H. 2005. Karakteristik reproduksi ikan endemik rainbow selebensis (Telmatherina celebencis Boulenger) di Danau Towuti. J. Penelitian Perikanan Indonesia, 11(2): 29-37. http://dx.doi.org/10.15578/jppi.11.2.2 005.29-37

Nasution A. 2009. Analisis Ekologi Ikan Kurau, Eleutheronema tetradactylum (Shaw, 1804) Pada Perairan Laut Bengkalis, Propinsi Riau. Tesis. Universitas Indonesia. Depok. 187 hlm.

Nikolsky, G.V. 1980. Theory of fish population dynamics. Bishen Sigh Mahendra Pal Singh, India and Ottokoeltz Science Publisher. Germany. 317 p.

Patnaik, S. 1970. A contribution to the fishery and biology of the chilks sahal Eleutheronema tetradactylum (WHAW). Prociding Indian National Science Academic, 36(1): 33-61.

Permatachani, A., B. Mennofatria, M.M. Kamal. 2016. Kajian stok ikan peperek (Leiognathus equulus) berdasarkan alat tangkap jaring rampus di Perairan Selat Sunda. J. Teknologi Perikanan dan Kelautan, 7(2):107-116. http:// dx.doi.org/10.24319/jtpk.7.107-116.

Sarasati, W, M. Boer dan Sulistiono. 2016. Status Stok Rastrelliger spp. sebagai Dasar Pengelolaan Perikanan. $J$. Perikanan Universitas Gadjah Mada, 18 (2):73-81.

Sparre, P. and S.C. Venema. 1999. Introduksi pengkajian stok ikan tropis buku I manual. Badan Penelitian dan Pengembangan Pertanian (penerjemah). Kerjasama Organisasi Pangan, Perserikatan Bangsa-Bangsa dengan Pusat Penelitian dan Pengembangan Perikanan. Jakarta. $438 \mathrm{hlm}$.

Steel, R.G.D. dan J.H. Torrie. 1993. Prinsip dan prosedur statistika suatu pendekatan biometrik. Gramedia Pustaka Utama. Jakarta. $90 \mathrm{hlm}$.

Sulistiono, K.D. Soenanthi, dan E. Yustina. 2009. Aspek reproduksi ikan lidah (Cynoglossus linguna) di Perairan Ujung Pangkah Jawa Timur. $J$. Ikhtiologi Indonesia, 9(1):175-85.

Suruwaky, A., M. dan E. Gunaisah. 2013. Identifikasi tingkat eksploitasi sumberdaya ikan kembung lelaki (Rastrelliger kanagurta) ditinjau dari hubungan panjang berat. J. Akuatika, 4(2):131-140.

Suwarni. 2009. Hubungan panjang-bobot dan faktor kondisi ikan butana (Acanthurus mata) yang tertangkap di sekitar Perairan Pantai Desa Mattiro Deceng, Kabupaten Pangkajene Kepulauan, Provinsi Sulawesi Selatan. J. Torani Ilmu Kelautan dan Perikanan, 19(3):160-165.

Udupa, K.S.1986. Statistical method of estimating the size of first mature in fishes. J. Fishbyte, 4(2): 8-10.

Utami, M.N.F., S. Redjeki, dan E. Supriyantini 2014. Komposisi isi lambung ikan kembung lelaki (Rastrelliger kanagurta) di Rembang. J. Marine Research, 2(3): 99-106.

Walpole, R.E. 1995. Pengantar Statistika. PT Gramedia Pustaka Utama. Jakarta. 516 hlm.

Wewengkang, I.T.J.E. 2002. Analisis sistem usaha penangkapan ikan layur (Trichiurus savala) di Palabuhanratu dan kemungkinan pengembangannya. Tesis. Institut Pertanian Bogor. Bogor. $128 \mathrm{hlm}$.

$\begin{array}{ll}\text { Diterima } & : 06 \text { April } 2018 \\ \text { Direview } & : 05 \text { Mei } 2018 \\ \text { Disetujui } & : \text { 05 Juli } 2018\end{array}$


